\title{
The Migration Pattern of Florida Seasonal Farmworkers ${ }^{1}$
}

\author{
Zhengfei Guan, Berdikul Qushim, Feng Wu, and Alicia Whidden²
}

\section{Introduction}

Seasonal farmworkers are an important part of the agricultural workforce in the United States. Most agricultural work is seasonal, which causes a seasonal shift in labor demand. For example, Florida's strawberry-harvesting season is from late November through March, while Michigan apples are harvested from August through October, and North Carolina blueberries are harvested from July through August. To secure more consistent and higher wages, farmworkers travel from one work site to another, often between different states, to work the seasonal agricultural jobs. Studies in the literature suggest serious labor shortages in US agriculture (Zahniser et al. 2012; Taylor, Charlton, and Yunez-Naude 2012; Guan et al. 2015). Regional labor migration plays an important role in addressing agricultural labor needs in the United States and alleviating labor shortages, in particular, for the labor-intensive specialty crop industries.

A recent study found that when the migration rate decreases, the total number of farmworkers available decreases, which significantly reduces farmers' ability to adjust to seasonal shifts in labor demand (Fan et al., 2015). Studies also show that labor migration can address demand shocks and facilitate macroeconomic development (Blanchard et al., 1992; Partridge and Rickman, 2006; Martin et al. 2007). When seasonal workers migrate across regions or crops, they pursue opportunities that increase their income, while addressing spatial and seasonal labor demand across states or regions. This benefits both the workers and the overall agricultural economy.

For individual farmers, however, seasonal labor migration could be a double-edged sword, because opportunities elsewhere mean competition, and they could lose a muchneeded labor force toward the end of the season when harvesting is yet to be finished. This study presents a picture of the migration pattern of seasonal workers in the Florida strawberry industry, which will help growers understand the sources of labor supply and competition, improve their predictions of labor shortages, and plan to better meet their needs for labor.

\section{Survey}

In spring 2016, we conducted a farm workers survey in the Florida strawberry industry, interviewing 470 migrant farmworkers. A part of the survey was to collect information on farmworkers' migration patterns. Respondents were asked to indicate crops they worked with and states where they worked before their current job - harvesting strawberries. The survey also asked the respondents to indicate crops and states they expected to work with/in after finishing their existing job. Crops listed in the questionnaire included: (1) blueberry, (2) tomato, (3) citrus, (4) apple, and (5) other vegetables or melons, which are major crops seasonal workers work with. To consider possibilities of other work, we also included the options of (6) other farm work, (7) non-farm work, and (8) not employed.

1. This document is FE1040, one of a series of the Food and Resource Economics Department, UF/IFAS Extension. Original publication date June2018. Visit the EDIS website at http://edis.ifas.ufl.edu.

2. Zhengfei Guan, assistant professor; Berdikul Qushim, postdoctoral research associate; Feng Wu, research assistant scientist; Food and Resource Economics Department, UF/IFAS Gulf Coast Research and Education Center, Balm, FL; and Alicia Whidden, UF/IFAS Extension agent for Hillsborough County, Seffner. FL 33584.

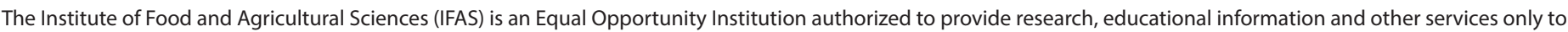

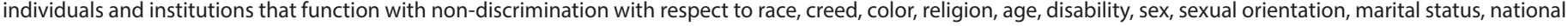
origin, political opinions or affiliations. For more information on obtaining other UF/IFAS Extension publications, contact your county's UF/IFAS Extension office. 


\section{Migration Patterns of Farmworkers}

Descriptive statistics of farmworkers' migration pattern by crop are presented in Table 1. It shows that before working on strawberries, out of 444 respondents, 142 (32\%) worked on blueberries, $144(32.4 \%)$ on tomatoes, $8(1.8 \%)$ on citrus, $69(15.5 \%)$ on apples, $45(10.1 \%)$ on other vegetable or melons, 104 (23.4\%) on other farm work (such as on other fruits, like grapes and peaches), 13 (2.9\%) on non-farm work, and 29 (6.5\%) did not work. Blueberries and tomatoes were the most common crops that workers worked before working on strawberries. Note that the total number of responses is greater than the number of respondents, indicating that some workers migrated more than once to work on multiple crops. Further analysis reveals that $2.2 \%$ of farmworkers migrated to two states to perform agricultural work, and $1 \%$ of farmworkers migrated to three or more states to perform agricultural work.

Expected migration choices for farmworkers by crop are shown in the last two columns of Table 1. Out of 441 workers, 183 (41.5\%) will likely work on blueberries, 130 (29.5\%) on tomatoes, $5(1.1 \%)$ on citrus, $45(10.2 \%)$ on apples, $39(8.8 \%)$ on other vegetable or melons, 61 (13.8\%) on other farm work, and 7 (1.6\%) on non-farm work; $20(4.5 \%)$ will not plan to work, and $22(5.0 \%)$ have not decided. The survey responses indicate that blueberries and tomatoes are major crops that farmworkers will work on after the strawberry season, suggesting that the annual migration pattern is stable.

Migration patterns by region and by state for workers are presented in Tables 2 and 3, respectively. We grouped five regions: Midwest, Northeast, Southeast, West, and other countries (including Mexico and other Central American countries) The Midwest region includes Illinois, Indiana, Michigan, Ohio, and Wisconsin. The Northeast region includes Connecticut, Delaware, New Jersey, New York, and Pennsylvania. The Southeast region includes Alabama, Georgia, Mississippi, North Carolina, South Carolina, Tennessee, Virginia, and West Virginia. The West region includes Arizona and California. For comparison purposes, we listed Florida separately. Table 2 shows that a total of 152 workers, accounting for $38.5 \%$ of respondents, migrated from other work sites in Florida to harvest strawberries. Migration within Florida dominates migrations from other regions to Florida. The results show that 95 workers (24.1\%) migrated from the Midwest to Florida, 27 (6.8\%) from the Northeast, 87 (22.0\%) from the Southeast, 30 (7.6\%) from the West, and only 4 (1.0\%) from other countries. Similarly, strawberry workers will most likely migrate to other work sites in Florida after the strawberry season concludes
(37.4\%) (Table 2). In addition, 77 (22.3\%) farmworkers indicated they will migrate to the Midwest, $26(7.5 \%)$ to the Northeast, $83(24.1 \%)$ to the Southeast, and $23(6.7 \%)$ to the West. These percentages were comparable to those before the job.

We further summarized migration of farmworkers among states. (Table 3). Florida ranked first both as origin and as destination for farmworkers, followed by Michigan, North Carolina, California, Georgia, and New Jersey. Since Florida is a major producer of fruits and vegetables in the United States, farmworkers need only to travel short distances to work on other crops, including blueberries and tomatoes, making it a major migration destination. However, migration to other states for agricultural work is also popular. For example, after finishing strawberries in Florida, 20.6\% workers will migrate to Michigan, $14.2 \%$ to North Carolina, $6.7 \%$ to California, $5.2 \%$ to Georgia, and $4.9 \%$ to New Jersey. When migrating to Michigan, farmworkers reported that they would most likely harvest apples and blueberries. Farmworkers would likely harvest apples in North Carolina, strawberries in California, and blueberries in both Georgia and New Jersey.

\section{Concluding Remarks}

Economic contributions of farmworkers to agriculture in the United States and the whole economy are directly influenced by farmworkers' migration patterns. According to the National Agricultural Workers Survey (NAWS), the migration rate of hired agricultural workers within the United States decreased by 30\% from 1998 to 2009. Dropping migration rate has been a concern for growers because they depend on seasonal workers to harvest their crops, particularly at the peak of harvesting time. This study tracks the migration of Florida strawberry farmworkers and presents a picture of the migration pattern. The results show that within-Florida migration accounts for the largest share of workforce and that Michigan and North Carolina are the second and third largest states where migrant workers work before and after the current job. Blueberries, tomatoes, and apples are the top three crops they work on before and after the job. 


\section{References}

Blanchard, O. J., L. F. Katz, R. E. Hall, and B. Eichengreen. 1992. "Regional Evolutions." Brookings Papers on Economic Activity 1992 (1): 1-75.

Fan, M., S. Gabbard, A. A. Pena, and J. M. Perloff. 2015.

"Why Do Fewer Agricultural Workers Migrate Now?"

American Journal of Agricultural Economics, Agricultural and Applied Economics Association 97(3): 665-679.

Guan, Z., F. Wu, R. Roka, and A. Whidden, A. 2015.

"Agricultural labor and immigration reform." Choices 30(4):

$1-9$.

Martin, P., S. Martin, and S. Cross. 2007. "High-level

Dialogue on Migration and Development." International

Migration 45(1) 7-25.

Partridge, M. D., and D. S. Rickman. 2006. "An SVAR

Model of Fluctuations in U.S. Migration Flows and State

Labor Market Dynamics." Southern Economic Journal 72(4):

958-980.

Taylor, J. E., D. Charlton, D., and A. Yúnez-Naude. 2012.

"The End of Farm Labor Abundance." Applied Economic

Perspectives and Policy 34(4): 587-598.

Zahniser, S., T. Hertz, P. Dixon, and M. Rimmer. 2012.

"Analyzing the Effects of Immigration Reforms on Agriculture." Choices 27(2). 
Table 1. Crops Worked before and after Current Job by Workers.

\begin{tabular}{|c|c|c|c|c|}
\hline \multirow[b]{2}{*}{ Crops } & \multicolumn{2}{|c|}{ Before Current Job } & \multicolumn{2}{|c|}{ After Current Job } \\
\hline & \# of Workers & Percent & \# of Workers & Percent \\
\hline Blueberry & 142 & 32.0 & 183 & 41.5 \\
\hline Tomato & 144 & 32.4 & 130 & 29.5 \\
\hline Citrus & 8 & 1.8 & 5 & 1.1 \\
\hline Apple & 69 & 15.5 & 45 & 10.2 \\
\hline Other vegetable/melons & 45 & 10.1 & 39 & 8.8 \\
\hline Other farm work & 104 & 23.4 & 61 & 13.8 \\
\hline Non-farm work & 13 & 2.9 & 7 & 1.6 \\
\hline Didn't work & 29 & 6.5 & - & - \\
\hline Don't work & & & 20 & 4.5 \\
\hline Don't know & - & - & 22 & 5.0 \\
\hline
\end{tabular}

Table 2. Migration among Regions by Farmworkers before and after the Current Job.

\begin{tabular}{|l|c|c|c|c|}
\hline & \multicolumn{2}{|c|}{ Before the Current Job } & \multicolumn{2}{c|}{ After the Current Job } \\
\hline \multicolumn{1}{|c|}{ Regions } & \# of Workers & Percent & \# of Workers & 129 \\
\hline Florida & 152 & 38.5 & 77 & 22.3 \\
\hline Midwest & 95 & 24.1 & 26 & 7.5 \\
\hline Northeast & 27 & 6.8 & 83 & 24.1 \\
\hline Southeast & 87 & 22.0 & 23 & 6.7 \\
\hline West & 30 & 7.6 & 0 & 0.0 \\
\hline Others & 4 & 1.0 & \\
\hline
\end{tabular}

Table 3. Migration among States by Farmworkers before and after Current Job.

\begin{tabular}{|c|c|c|c|c|}
\hline \multirow[b]{2}{*}{ Regions } & \multicolumn{2}{|c|}{ Before Current Job } & \multicolumn{2}{|c|}{ After Current Job } \\
\hline & \# of Workers & Percent & \# of Workers & Percent \\
\hline Florida & 152 & 38.5 & 129 & 37.4 \\
\hline Michigan & 82 & 20.8 & 71 & 20.6 \\
\hline North Carolina & 52 & 13.2 & 49 & 14.2 \\
\hline California & 30 & 7.6 & 23 & 6.7 \\
\hline Georgia & 17 & 4.3 & 18 & 5.2 \\
\hline New Jersey & 15 & 3.8 & 17 & 4.9 \\
\hline
\end{tabular}

